\title{
Blockade of Tetrahydrobiopterin Synthesis Protects Neurons after Transient Forebrain Ischemia in Rat: A Novel Role for the Cofactor
}

\author{
Sunghee Cho, ${ }^{1}$ Bruce T. Volpe, ${ }^{1}$ Youngmee Bae, ${ }^{1}$ Onyou Hwang, ${ }^{2}$ Hyun J. Choi, ${ }^{2}$ Judit Gal, ${ }^{1}$ Larry C. H. Park, ${ }^{1}$ \\ Chung K. Chu, ${ }^{3}$ Jinfa Du, ${ }^{3}$ and Tong H. Joh ${ }^{1}$ \\ ${ }^{1}$ Department of Neurology and Neuroscience, Cornell University Medical College at W. M. Burke Medical Research \\ Institute, White Plains, New York 10605, 2Department of Biochemistry, University of Ulsan College of Medicine, Seoul, \\ 138-736 Korea, and ${ }^{3}$ Center for Drug Discovery, Department of Pharmaceutical and Biomedical Sciences, College of \\ Pharmacy, The University of Georgia, Athens, Georgia 30602
}

The generation of nitric oxide (NO) aggravates neuronal injury. (6R)-5,6,7,8-Tetrahydro-L-biopterin $\left(\mathrm{BH}_{4}\right)$ is an essential cofactor in the synthesis of NO by nitric oxide synthase (NOS). We attempted to attenuate neuron degeneration by blocking the synthesis of the cofactor $\mathrm{BH}_{4}$ using $\mathrm{N}$-acetyl-3-O-methyldopamine (NAMDA). In vitro data demonstrate that NAMDA inhibited GTP cyclohydrolase I, the rate-limiting enzyme for $\mathrm{BH}_{4}$ biosynthesis, and reduced nitrite accumulation, an oxidative metabolite of $\mathrm{NO}$, without directly inhibiting NOS activity. Animals exposed to transient forebrain ischemia and treated with NAMDA demonstrated marked reductions in ischemia-induced $\mathrm{BH}_{4}$ levels, NADPH- diaphorase activity, and caspase-3 gene expression in the CA1 hippocampus. Moreover, delayed neuronal injury in the CA1 hippocampal region was significantly attenuated by NAMDA. For the first time, these data demonstrate that a cofactor, $\mathrm{BH}_{4}$, plays a significant role in the generation of ischemic neuronal death, and that blockade of $\mathrm{BH}_{4}$ biosynthesis may provide novel strategies for neuroprotection.

Key words: tetrahydrobiopterin $\left(\mathrm{BH}_{4}\right)$; selective neuronal injury; CA1 hippocampus; transient forebrain ischemia; neuroprotection; N-acetyl-3-O-methyldopamine
Nitric oxide (NO) and other free radicals have been implicated in the pathophysiology of ischemic neuronal death (Patt et al., 1988; Beckman et al., 1990; Dawson et al., 1991b; Kader et al., 1993; Pahlmark et al., 1993). NO, synthesized from L-arginine by the enzyme nitric oxide synthase (NOS), is an important signaling molecule in normal synaptic transmission but can be a neurotoxin under pathological conditions. Increases in NO generation, NOS mRNA, and protein were reported in animal models of ischemia (Kader et al., 1993; Z hang et al., 1994; Iadecola et al., 1995a,b; for review, see Iadecola, 1997), and NOS inhibitors protected neurons in these animal models (Buisson et al., 1992; Nagafuji et al., 1992; Ashwal et al., 1993; Hamada et al., 1994; Huang et al., 1994; Shapiro et al., 1994; Kohno et al., 1995, 1996; Izumi et al., 1996) (also see Dawson et al., 1992). The mechanism by which NO contributes to ischemic neuronal death, either through necrosis or apoptosis, is not known. However, NO-mediated hydrolytic cleavage of poly(ADP-ribose)-polymerase, one of the key substrates for activated cysteine protease (Bonfoco et al., 1996; Messmer et al., 1996), suggests that NO plays a role in apoptotic cell death.

(6R)-5,6,7,8-Tetrahydro-L-biopterin $\left(\mathrm{BH}_{4}\right)$ is an essential cofactor for the activation of all isoforms of NOS (Kwon et al., 1989; Tayeh and Marletta, 1989; Gross et al., 1991). It is synthesized from GTP via sequential enzyme reactions catalyzed by GTPcyclohydrolase I (GTPCH), 6-pyruvoyl-tetrahydropterin syn-

\footnotetext{
Received Sept. 23, 1998; revised Nov. 5, 1998; accepted Nov. 6, 1998
}

This work was supported by National Institute of Mental Health Grant 24285 to T.H.J., funds from the 98KOSEF postdoctoral training program to H.J.C., 97 Academic Research Fund of Ministry of Education, Republic of Korea, to O.H., and Burke Medical Research Institute.

Correspondence should be addressed to Dr. Tong H. Joh, Department of Neurology and Neuroscience, Cornell University Medical College at W. M. Burke Medical Research Institute, 785 Mamaroneck Avenue, White Plains, NY, 10605. Copyright (C) 1999 Society for Neuroscience 0270-6474/99/190878-12\$05.00/0 thase, and sepiapterin reductase. It was reported that cytokineinduced NO production requires $\mathrm{GTPCH}$ activation in cardiac myocytes (Oddis and Finkel, 1996). Also, increased $\mathrm{BH}_{4}$ levels in murine fibroblasts (Werner-Felmayer et al., 1990), cardiac myocytes (Kasai et al., 1997), and endothelial cells (Werner-Felmayer et al., 1993; Rosenkranz-Weiss et al., 1994) indicate that the availability of the cofactor regulates NOS activity.

We hypothesized that ischemia increases the $\mathrm{BH}_{4}$ level and that the increased $\mathrm{BH}_{4}$ level plays a critical role in selective neuronal injury via NOS activation. We tested whether blockade of $\mathrm{BH}_{4}$ biosynthesis could protect neurons. First, we synthesized a new $\mathrm{BH}_{4}$ synthesis inhibitor $\mathrm{N}$-acetyl-3-O methyldopamine (NAMDA), an analog of $N$-acetyldopamine, and tested whether it inhibited GTPCH, NOS, and NADPHdiaphorase (NADPH-D) activity in an immortalized murine microglial cell line (BV-2; Blasi et al., 1990). Then, to explore the possibility that upstream regulation of $\mathrm{BH}_{4}$ protected neurons, animals were exposed to transient forebrain ischemia. We tested whether treatment with NAMDA changed $\mathrm{BH}_{4}$ levels, NADPH-D activity, and cysteine protease (caspase) gene expression in the CA1 hippocampus and, ultimately, whether this treatment altered the number of neurons in the CA1 hippocampus.

\section{MATERIALS AND METHODS}

Synthesis of NAMDA. 3-O-Methyldopamine hydrochloride (1 gm, 4.9 $\mathrm{mmol}$; Aldrich, Milwaukee, WI) was suspended in $10 \mathrm{ml}$ of methylene chloride and $2 \mathrm{ml}$ of triethylamine. Acetyl anhydride $(1 \mathrm{gm}, 9.8 \mathrm{mmol})$ was added to the suspension, and the solution was refluxed for $3 \mathrm{hr}$. Solvent was removed in vacuo, and the residue was redissolved in $10 \mathrm{ml}$ of methanol. Potassium carbonate $(200 \mathrm{mg})$ was then added and stirred at room temperature for $3 \mathrm{hr}$. Methanol was removed, and the residue was purified by silica gel column chromatography (methanol, $5 \%$ : chloroform, $95 \%$ ) to give $N$-acetyl-3- $O$-methyldopamine ( $930 \mathrm{mg}, 91 \%$ ) as a semisyrup, which solidified. The chemical structure of the synthesized 
compound was identified by spectroscopic analyses: nuclear magnetic resonance $\left(\mathrm{DMSO}_{-\mathrm{d} 6}\right) \delta 8.71\left(\mathrm{~s}, 1 \mathrm{H}, \mathrm{OH}, \mathrm{D}_{2} \mathrm{O}\right.$ exchangeable), 7.87 (br t, $J=4.8,1 \mathrm{H}, \mathrm{NH}, \mathrm{D}_{2} \mathrm{O}$ exchangeable $), 6.73(\mathrm{~d}, J=1.6 \mathrm{~Hz}, 1 \mathrm{H}, 2-\mathrm{H}), 6.67$ $(\mathrm{d}, J=8 \mathrm{~Hz}, 1 \mathrm{H}, 5-\mathrm{H}), 6.57(\mathrm{dd}, J=1.6,8 \mathrm{~Hz}, 6-\mathrm{H}), 3.74\left(\mathrm{~s},{ }^{3} \mathrm{H}, \mathrm{OCH}_{3}\right)$, $3.18,2.57\left(\mathrm{q}, \mathrm{t}, J=7.6,7.2 \mathrm{~Hz}, 4 \mathrm{H}, \mathrm{CH}_{2} \mathrm{CH}_{2}\right), 1.78\left(\mathrm{~s},{ }^{3} \mathrm{H}, \mathrm{Ac}\right)$. Analytical calculated for $\mathrm{C}_{11} \mathrm{H}_{15} \mathrm{NO}_{3} . \mathrm{H}_{2} \mathrm{O}$ : C, 60.66; H, 7.02; N, 6.36. Found: C, 60.56; H, 7.04; N, 6.29. MS $m / z, 210\left[\mathrm{M}^{+} \mathrm{H}\right]^{+}$.

Nitrite measurement in the $B V-2$ cell line. The immortalized murine $\mathrm{BV}-2$ cell line was shown to exhibit phenotypic and functional properties of reactive microglial cells (Blasi et al., 1990, Bocchini et al., 1992). The cells were grown and maintained in DMEM (Life Technologies, Grand Island, NY) supplemented with $10 \%$ fetal calf serum and penicillinstreptomycin at $37^{\circ} \mathrm{C}$ in a humidified incubator under $5 \% \mathrm{CO}_{2}$. The cells were grown in 24 well culture plates and treated for $6 \mathrm{hr}$ with $0,0.05,0.5$, 2 , or $5 \mathrm{~mm}$ NAMDA either in the presence or absence of $0.2 \mu \mathrm{g} / \mathrm{ml}$ lipopolysaccharide (LPS; Sigma, St. Louis, MO). Accumulated nitrite, an oxidative metabolite of NO, was measured in the cell supernatant by the Griess reaction (Green et al., 1982). Briefly, $200 \mu$ l aliquots of cell supernatant from each well were mixed with $100 \mu \mathrm{l}$ of Griess reagent $[1 \%$ sulfanilamide (Fluka, Ronkonkoma, NY), 0.1\% naphthylethylenediamine dihydrochloride (Fluka), and $\left.2.5 \% \mathrm{H}_{3} \mathrm{PO}_{4}\right]$ in a 96 well microtiter plate, and the absorbance was read at $540 \mathrm{~nm}$ using a plate reader. After the supernatant was removed, the cells were either dissociated to count total cell number using the trypan blue exclusion method or immediately fixed with $4 \%$ paraformaldehyde for $30 \mathrm{~min}$ to perform NADPH-D histochemical staining.

NADPH-D histochemistry. NOS-containing neurons are visualized by histochemical staining for NADPH-D because NOS catalytic activity accounts for the staining (Dawson et al., 1991a; Hope et al., 1991). The histochemical staining was performed according to the method described by Vincent and Kimura (1992). Either fixed BV-2 cells [15 min fix with $4 \%$ paraformaldehyde (PFA)] or tissue sections (2 hr post-fix with $4 \%$ PFA) were incubated for $1 \mathrm{hr}$ at $37^{\circ} \mathrm{C}$ with a solution containing $1 \mathrm{mg} / \mathrm{ml}$ NADPH, $0.25 \mathrm{mg} / \mathrm{ml}$ nitroblue tetrazolium (Sigma), and $0.3 \%$ Triton $\mathrm{X}-100$ in $0.1 \mathrm{M}$ phosphate buffer (PB). The reaction was terminated by the addition of cold $0.1 \mathrm{M} \mathrm{PB}$.

Because the intensity of NADPH-D staining depends on post-fixation time, $15 \mathrm{~min}$ (for cells) and $2 \mathrm{hr}$ (for tissue) post-fixation times were strictly used. Sections from control, saline-treated ischemic, and NAMDA-treated ischemic rats were nick-marked and incubated in the same well. To quantitate NADPH-D activity 24 and $48 \mathrm{hr}$ after ischemia, the optical density of staining in the CA1 pyramidal layer was projected onto a video monitor and analyzed as has been described (Cubells et al., 1995). Image analysis was performed by an investigator blinded to the experimental condition. Mean optical density was calculated from four images per animal, and there were three or four animals from the control, saline-treated ischemic, and NAMDA-treated ischemic groups.

GTPCH activity. The activity of GTPCH was determined by the method of Sawada et al. (1986). Briefly, BV-2 cells were homogenized in $200 \mu \mathrm{l}$ of $0.1 \mathrm{M}$ Tris-HCl, pH 7.8, containing $0.3 \mathrm{M} \mathrm{KCl}, 2.5 \mathrm{~mm}$ EDTA, and $10 \%$ glycerol and sonicated. The reaction mixture $(250 \mu \mathrm{l})$ containing $0.1 \mathrm{M}$ Tris-HCl, pH 7.8, $0.3 \mathrm{M} \mathrm{KCl}, 2.5 \mathrm{~mm}$ EDTA, $10 \%$ glycerol, and $0.6 \mathrm{~mm}$ GTP was added to $100 \mu \mathrm{l}$ of the enzyme preparation and incubated for $15 \mathrm{~min}$ at $37^{\circ} \mathrm{C}$ in the dark. The reaction was terminated by the addition of $20 \mu \mathrm{l}$ of $1 \mathrm{M} \mathrm{HCl}$ solution. The mixture was oxidized by the addition of $10 \mu \mathrm{l}$ of iodine solution $\left(8 \% \mathrm{I}_{2} / 16 \% \mathrm{KI}\right)$ in the dark for $10 \mathrm{~min}$. Iodine oxidation was stopped by the addition of $10 \mu \mathrm{l}$ of $8 \%$ ascorbate. After the addition of $30 \mu \mathrm{l}$ of $1.0 \mathrm{~N} \mathrm{NaOH}$, the mixture was incubated with $3.5 \mathrm{U}$ of alkaline phosphatase at $37^{\circ} \mathrm{C}$ for $1 \mathrm{hr}$. The reaction was stopped by the addition of $50 \mu \mathrm{l}$ of $\mathrm{HCl}$, and the supernatant, after centrifugation, was analyzed by an HPLC-fluorometric detection system with $10 \mathrm{~mm}$ sodium phosphate buffer, $\mathrm{pH} 7.0$, as carrier buffer. The enzyme activity was expressed as femtomoles of neopterin per hour per cell.

NOS activity. BV-2 microglial cells $\left(2 \times 10^{6}\right)$ were activated with LPS to induce inducible NOS (iNOS). To obtain a cell extract, cells were washed at the end of $6 \mathrm{hr}$ of incubation with $0.1 \mathrm{M} \mathrm{PBS}$, collected, homogenized in $100 \mu \mathrm{l}$ of $25 \mathrm{~mm}$ Tris-HCl, pH 7.4, containing $1 \mathrm{~mm}$ EDTA and $1 \mathrm{~mm}$ EGTA using Qia Shredder columns (Qiagen, Chatsworth, CA), and then centrifuged at full speed for $5 \mathrm{~min}$ in a microcentrifuge. Cell extracts were kept frozen at $-80^{\circ} \mathrm{C}$ until use. A NOS detection assay kit (Stratagene, La Jolla, CA) was used to measure NOS activity by monitoring the conversion of $\left[{ }^{3} \mathrm{H}\right] \mathrm{L}$-arginine to $\left[{ }^{3} \mathrm{H}\right] \mathrm{L}$ citrullin. Cell extracts $(5 \mu \mathrm{l}, 10 \mu \mathrm{g}$ of protein $/ \mu \mathrm{l})$ were added to $40 \mu \mathrm{l}$ of reaction mixture containing NADPH and $\left[{ }^{3} \mathrm{H}\right]$ arginine either in the absence (control) or presence of increasing concentrations of NAMDA $(0.05-5 \mathrm{mM})$. To chemically inhibit the control reaction, $5 \mu \mathrm{l}$ of the inhibitor $N \omega$-nitro-L-arginine methyl ester $\mathrm{HCl}$ (NNAME) was added before adding the cell extract. The rest of the steps were followed according to the manufacturer's instructions, and radioactive counts in the reaction mixture were quantitated in a liquid scintillation counter.

$\mathrm{BH}_{4}$ determination. The CA1 region of the hippocampus was dissected under a dissecting microscope. Total biopterin content was determined according to the method of Fukushima and Nixon (1980). Briefly, the dissected tissues pooled from each hemisphere were homogenized in 1 $\mathrm{ml}$ of $0.1 \mathrm{~N}$ phosphoric acid, mixed with $0.2 \mathrm{ml}$ of acidic iodine solution $\left(0.5 \% \mathrm{I}_{2} / 1.0 \% \mathrm{KI}\right.$ in $0.2 \mathrm{~N}$ TCA), and incubated in the dark for $1 \mathrm{hr}$ at room temperature. Iodine oxidation was terminated by the addition of $0.1 \mathrm{ml}$ of $1 \%$ ascorbic acid. The mixture was then centrifuged at $8000 \times$ $g$ for $15 \mathrm{~min}$, and the supernatant was diluted with distilled water and analyzed using an HPLC-fluorometric detection system with 5\% methanol as mobile phase. Biopterine content was expressed as $\mu \mathrm{g} / \mathrm{mg}$ of tissue.

Four-vessel occlusion ischemia. Animal surgery was in compliance with American Association of the Accreditation of Laboratory Animal Care guidelines set forth in the Public Health Service manual Guide in the Care and Use of Laboratory Animals. Animals (male Wistar rats, 200-250 gm; Hill Top, Scottsdale, AZ) were anesthetized with a mixture of halothane $(1 \%)$, oxygen, and nitrogen and surgically prepared for four-vessel occlusion (4-VO) according to the method described by Pulsinelli et al. (1982). Briefly, we used reversible clasps to encircle each common carotid artery, electrocauterization to occlude both vertebral arteries, and an adjustable neck suture to control collateral blood flow to the brain. Food was withheld overnight, but water was freely available. On the following day, $10 \mathrm{~min}$ of $4-\mathrm{VO}$ ischemia was induced by tightening the clasps around the common carotid arteries and the suture. To minimize variability, the following criteria were applied: loss of righting reflex and bilateral pupil dilation during the entire ischemic period and $20 \pm 5 \mathrm{~min}$ of postischemic coma after $10 \mathrm{~min}$ of ischemia. The body temperature of all animals was kept at $37.5 \pm 0.5^{\circ} \mathrm{C}$ by a thermocouple-regulated heating lamp during ischemia and reperfusion until the animals regained consciousness and reestablished thermohomeostasis.

NAMDA administration. Animals subjected to $10 \mathrm{~min}$ of ischemia were randomly divided into four groups. The animals received one of the following triple intraperitoneal injections: (1) saline at $0,0.5$, and $2 \mathrm{hr}$; (2) NAMDA (10 mg/kg) at $0,0.5$, and $2 \mathrm{hr}$; (3) NAMDA at 1, 1.5, and $3 \mathrm{hr}$; or (4) NAMDA at 2, 2.5, and $4 \mathrm{hr}$ of cerebral reperfusion. To examine whether NAMDA causes hypothermia, the animals' body temperatures were recorded for the first $4 \mathrm{hr}$ of cerebral reperfusion. Sham-operated animals that underwent surgery and carotid manipulation were used for nonischemic controls.

Tissue preparation. Animals were anesthetized with sodium pentobarbital $(120 \mathrm{mg} / \mathrm{kg})$ and perfused transcardially with saline containing $0.5 \%$ sodium nitrite and $10 \mathrm{U} / \mathrm{ml}$ heparin sulfate followed by $4 \%$ cold formaldehyde in $0.1 \mathrm{M}$ sodium phosphate buffer $(\mathrm{PB}, \mathrm{pH} 7.2)$. The brains were further post-fixed for $2 \mathrm{hr}$ and stored in a $30 \%$ sucrose solution overnight. Using a sliding microtome, the dorsal hippocampus between bregma -2.5 and $-4.0 \mathrm{~mm}$ was sectioned at a thickness of either $30 \mu \mathrm{m}$ for NADPH-D histochemical staining and neuronal density measurements or $40 \mu \mathrm{m}$ for in situ hybridization. For the measurement of neuronal density, sections were mounted on slides and stained with cresyl violet to visualize neurons.

In situ hybridization. Caspase-3 (Cpp32) and caspase-1 (ICE) genes were cloned by PCR using a mouse brain cDNA library. Primers were designed according to published sequence, and the clones obtained were confirmed by sequencing: primer for caspase-3 (Cpp32), $5^{\prime}$ end primer, 5'-AACCTCAGAGAGACATTCATGG-3'; 3' end primer, 5'-CGTGAGCATGGACACAATACACGG-3' (nucleotides 274-867); caspase-1 (ICE), 5' end primer, 5'-GTACACGTCTTGCCCTCATTATC-3'; 3' end primer, 5'-GTCACAAGACCAGGCATATTCTTTC-3' (nucleotides 481-1091). All reagents for in situ hybridization were made up with diethyl pyrocarbonate-treated water. Hippocampal sections from control, saline-ischemic, and NAMDA-treated ischemic animals were collected in the same vial containing $2 \times \mathrm{SSC}(1 \times \mathrm{SSC}=0.15 \mathrm{M} \mathrm{NaCl}$ and 0.015 $\mathrm{M}$ sodium citrate) to ensure that they were subjected to identical hybridization conditions for each probe. ${ }^{35} \mathrm{~S}$-labeled mouse caspase- 3 and caspase-1 cDNA probes were prepared by the random primer method (random prime labeling kit; Boehringer Mannheim, Indianapolis, IN). The procedure for hybridization was followed by the method described by Stone et al. (1990). Briefly, free-floating sections were prehybridized 


\begin{tabular}{|c|c|c|c|c|c|}
\hline \multirow{2}{*}{$\begin{array}{l}\text { Cell no. } \\
\left(\times 10^{5}\right)\end{array}$} & \multicolumn{5}{|c|}{ NAMDA (mM) } \\
\hline & 0 & 0.05 & 0.5 & 2 & 5 \\
\hline No LPS & $36.9 \pm 1.5$ & $38.9 \pm 1.6$ & $42.7 \pm 3.2$ & $38.4 \pm 2.6$ & $33.8 \pm 1.9$ \\
\hline With LPS & $37.3 \pm 4.5$ & $39.8 \pm 3.1$ & $35.2 \pm 2.5$ & $30.4 \pm 1.7$ & $30.7 \pm 1.7$ \\
\hline
\end{tabular}

$\overline{\text { Total BV-2 microglial cell number was counted by the trypan blue exclusion method }}$ after incubation with different concentrations of NAMDA for $6 \mathrm{hr}$ both in the absence and presence of $0.2 \mu \mathrm{g} / \mathrm{ml}$ LPS. Data were obtained from two independent experiments $(n=4$ each) and expressed as a mean \pm SEM. ANOVA, NewmanKeuls multiple comparison test, $p>0.05$, NS.

for $2 \mathrm{hr}$ in $50 \%$ formamide, $10 \%$ dextran, $2 \times \mathrm{SSC}, 1 \times$ Denhardt's solution, $10 \mathrm{~mm}$ dithiothreitol, and $0.5 \mathrm{mg} / \mathrm{ml}$ salmon sperm DNA. Denatured probes $\left(1 \times 10^{7} \mathrm{cpm} / \mathrm{ml}\right)$ were added to the prehybridization mixture and hybridized at $48^{\circ} \mathrm{C}$ overnight in a humidified chamber. The sections were washed in serial dilutions of SSC $(2 \times$ to $0.1 \times \mathrm{SSC})$ at $48^{\circ} \mathrm{C}$, dried, and exposed to Eastman Kodak (Rochester, NY) XAR-5 film for $3-5 \mathrm{~d}$ at $4^{\circ} \mathrm{C}$.

To quantitate the optical density of caspase-3 gene expression, the CA1 pyramidal layer and the adjacent stratum lucidum on the $\mathrm{x}$-ray autoradiogram was projected onto a video monitor and analyzed as above (Cubells et al., 1995). Image analysis was performed by an investigator blinded to the experimental condition. The optical density of the stratum lucidum was subtracted from the optical density of the CA1 pyramidal layer. Mean optical density was calculated from four images per animal. There were three or four animals from the control, salinetreated ischemic, and NAMDA-treated ischemic groups. Some slides were dipped in Kodak NTB-2 emulsion, exposed at $4^{\circ} \mathrm{C}$ for $3-4$ weeks, and developed for photomicrographs.

Cell density measurements. An unbiased morphometric strategy was used to measure neuronal density in the CA1 region of the hippocampus (Cho et al., 1997; Volpe et al., 1998). Briefly, a $100 \times 100 \mu \mathrm{m}$ frame $(10$ boxes on a side) was placed so that its vertical axis was perpendicular to the stratum pyramidale, and then this frame was systematically passed along the entire length of the CA1 region. All sections were viewed under oil with a 1.2 numerical aperture lens. The CA1-CA2 border was identified by the change in neuron shape and packing density. For each animal, neurons in the right and left strata pyramidale were sampled from comparable regions of the anterior dorsal hippocampus (bregma $-3.2 \mathrm{~mm}$ ) and the posterior dorsal hippocampus (bregma $-3.8 \mathrm{~mm}$ ). Four sections, at least $300 \mu \mathrm{m}$ apart, were obtained from each animal. The number of neurons counted was divided by the total volume sampled to generate the density of neurons in CA1. Mean neuron density was calculated for the left and right sides of the hippocampus and for the anterior and posterior regions for each animal.

Data analysis. All data are reported as mean \pm SEM. Comparison of GTPCH activity, nitrite accumulation, NOS activity at different concentrations of NAMDA versus control in vitro, NADPH-D staining, and caspase-3 mRNA expression at different treatments (either saline or NAMDA) versus sham control in vivo were made using ANOVA and a post hoc Newman-Keuls multiple comparison test. Neuron density was analyzed in a three-factor (treatment, region, and side) ANOVA followed by post hoc Fisher's PLSD tests.

\section{RESULTS}

\section{Synthesis and characterization of NAMDA}

After synthesis, we tested the effect of NAMDA on the viability of BV-2 microglial cells. There were no apparent changes in the morphology of the cells incubated with concentrations up to $5 \mathrm{~mm}$ NAMDA for $24 \mathrm{hr}$ on light microscopic examination. Furthermore, the microglial cell number determined by the trypan blue exclusion method was not affected after $6 \mathrm{hr}$ of incubation with different concentrations of NAMDA (0.05-5.0 mM) (Table 1). Addition of LPS did not affect the viability of cells treated with NAMDA (Table 1).

\section{Effects of NAMDA on nitrite level and NADPH-D and GTPCH activity in BV-2 microglial cells}

To test whether NAMDA attenuated NO production in BV-2 cells, nitrite levels in the culture medium were measured. There was a low but measurable amount of nitrite in the absence of LPS at the end of the $6 \mathrm{hr}$ incubation, which was not affected by treatment with different concentrations of NAMDA (Fig. 1). On the other hand, LPS increased the nitrite level by fivefold to sixfold compared with control. Importantly, the addition of NAMDA significantly reduced the LPS-induced nitrite accumulation in a dose-dependent manner (Fig. 1).

The NADPH-D histochemical staining was consistent with the nitrite level (see Fig. 1). In the absence of LPS, there was little NADPH-D activity (Fig. $2 A$ ), and the baseline intensity of staining was not affected by treatment with $5 \mathrm{~mm}$ NAMDA (data not shown). In contrast, LPS produced a marked increase in NADPH-D activity (Fig. $2 B$ ), which was attenuated by treatment with 5 mM NAMDA (Fig. $2 C$ ).

To determine whether NAMDA inhibited LPS-induced NO synthesis by blockade of the $\mathrm{BH}_{4}$ biosynthetic pathway, the activity of GTPCH was measured in BV-2 microglial cells in the presence of LPS. GTPCH activity in the cells treated with NAMDA was significantly reduced in a dose-dependent manner (Fig. 1).

\section{Direct effects of NAMDA on NOS activity}

To determine whether NAMDA inhibited NOS independent of its effects on GTPCH, NOS activity was measured in BV-2 cell extract. The data show that increasing concentrations of NAMDA (0.05-5 mM) had no effect on NOS activity (Fig. 3), but a known inhibitor, NNAME, inhibited control NOS activity significantly ( $28 \%$ of control). The in vitro data indicate that NAMDA attenuated nitrite production by GTPCH inhibition and not through NOS inhibition. Taken together, NAMDA attenuated NADPH-D activity by decreasing $\mathrm{BH}_{4}$ synthesis without apparent toxicity and without directly inhibiting NOS activity.

\section{$\mathrm{BH}_{4}$ measurements in the CA1 hippocampus after ischemia}

In animals exposed to ischemia, $\mathrm{BH}_{4}$ levels measured in the CA1 hippocampus during the postischemic period was significantly increased $24 \mathrm{hr}$ after ischemia (Fig. 4). Treatment with NAMDA (10 $\mathrm{mg} / \mathrm{kg}$ at $0,0.5$, and $2 \mathrm{hr}$ of cerebral reperfusion) prevented the rise in $\mathrm{BH}_{4}$ (Fig. 4). These results indicate that NAMDA inhibits GTPCH activity and decreases $\mathrm{BH}_{4}$ levels in vivo.

\section{Intrinsic NADPH-D-positive neurons in the CA1 hippocampus}

Using NADPH-D histochemical staining, we located NOScontaining neurons at the level of anterior dorsal hippocampus of unoperated animals. Intensely stained NADPH-D + neurons were found throughout in the CA1 pyramidal layer (Fig. 5A,B) but were scarce in the CA2-CA4 pyramidal layers (Fig. $5 C, D$ ). In dentate gyrus, intensely stained NADPH-D+ neurons were largely located adjacent to but not within the granular cell layer (Fig. 5D). These observations indicated that the distribution of NADPH-D + neurons favored the CA1 pyramidal layer of the dorsal hippocampus that has been demonstrated to be selectively vulnerable to ischemic challenge.

\section{NADPH-D activity in the ischemic CA1 hippocampus}

To investigate whether the ischemia-induced increase in $\mathrm{BH}_{4}$ levels resulted in a subsequent increase in NOS catalytic activity 


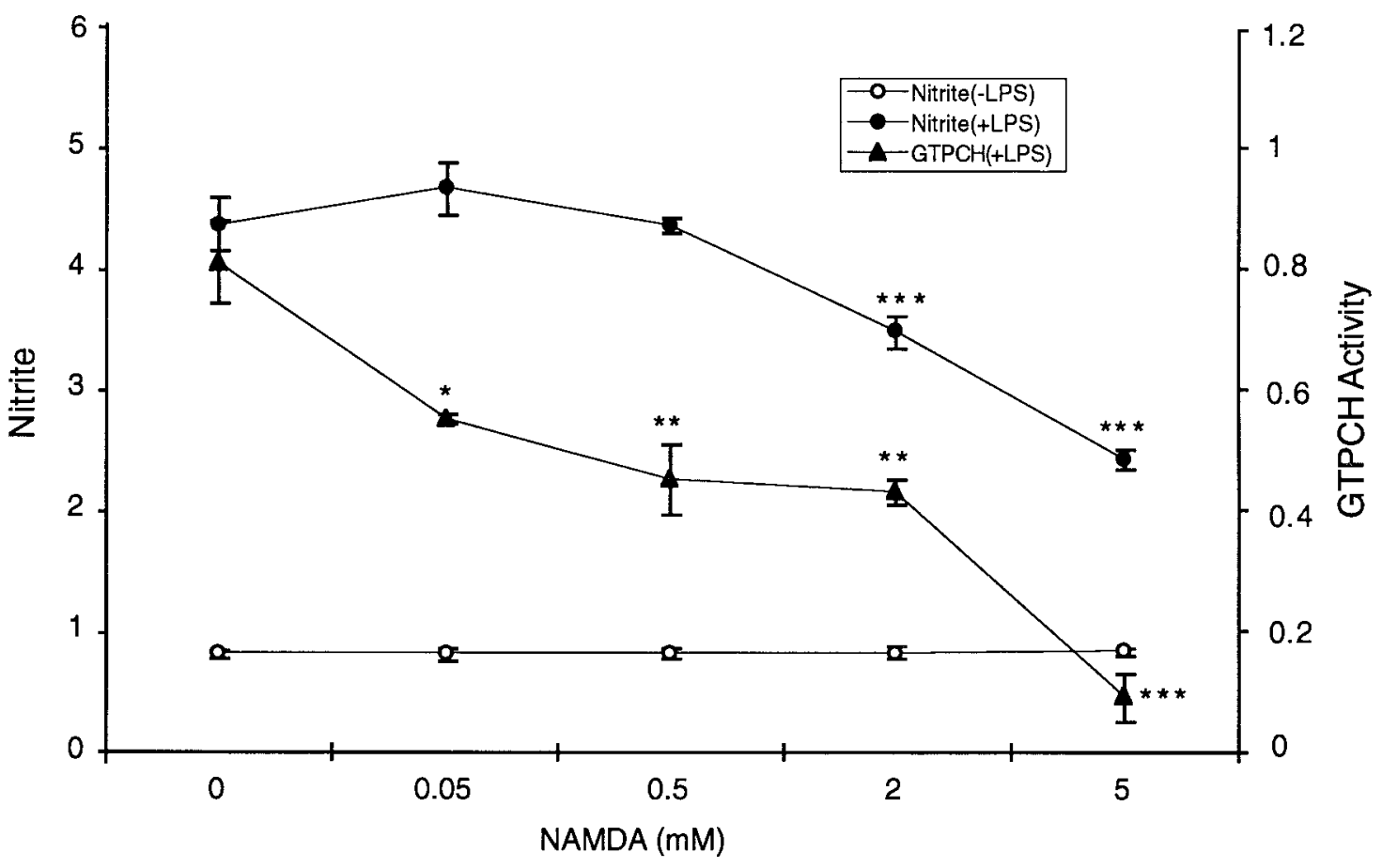

Figure 1. Nitrite levels and GTPCH activity in BV-2 microglial cells. In the presence of LPS $(0.2 \mu \mathrm{g} / \mathrm{ml})$, the addition of NAMDA significantly reduced accumulated nitrite levels in supernatant and GTPCH activity in the cells. Data were obtained from two independent experiments $(n=4$ each) and are expressed as mean \pm SEM. Nitrite levels are expressed as femtomoles per cell, and GTPCH activity is expressed as femtomoles of neopterin per hour per cell. ${ }^{*} p<0.05 ;{ }^{* *} p<0.01 ;{ }^{* * *} p<0.001$ versus 0 mM NAMDA, one-way ANOVA, Newman-Keuls multiple comparison test.
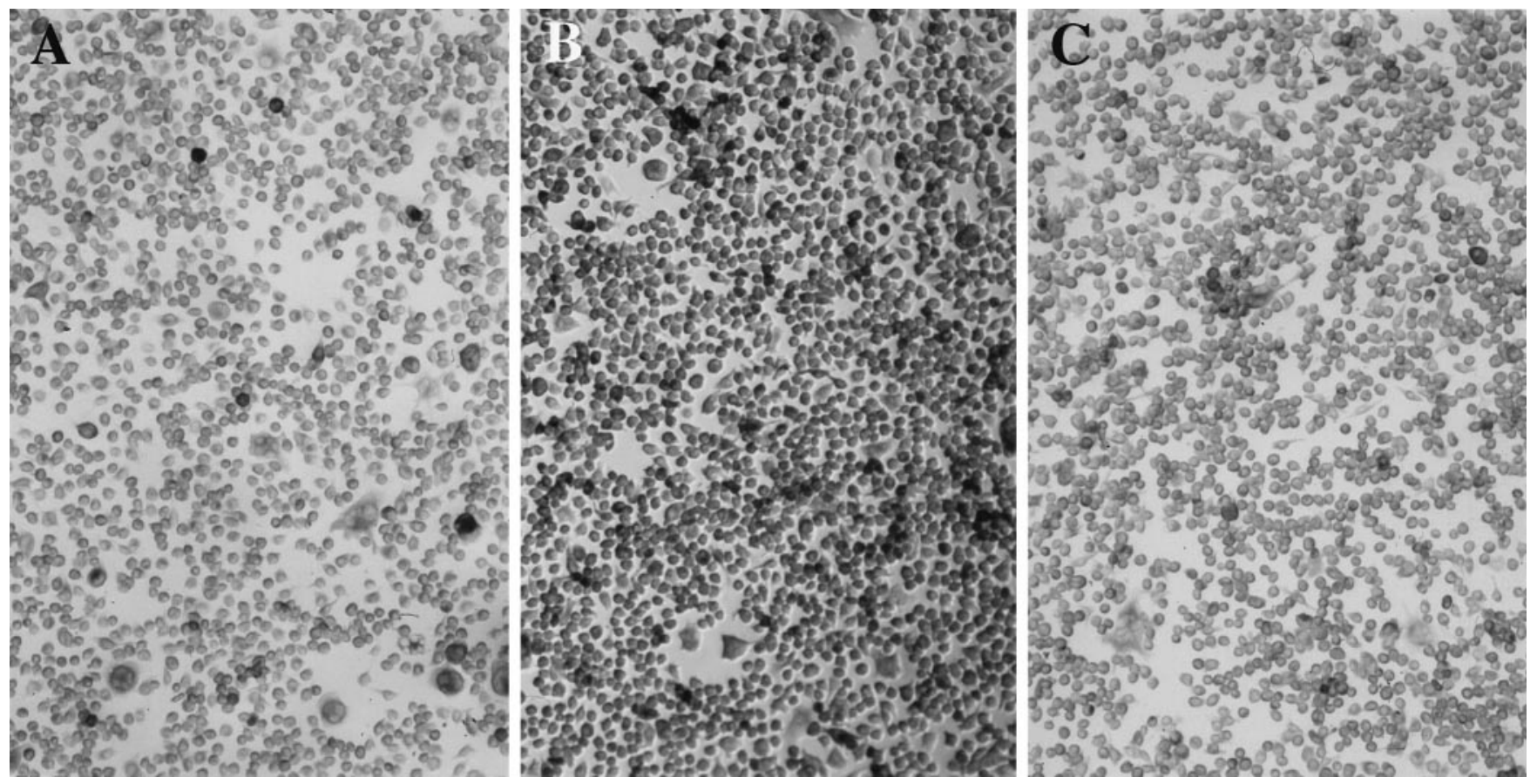

Figure 2. NADPH-D histochemical staining in BV-2 microglial cells. NADPH-D staining was performed in the absence of LPS $(A)$, the presence of LPS $(0.2 \mu \mathrm{g} / \mathrm{ml}, B)$, and the presence of LPS $(0.2 \mu \mathrm{g} / \mathrm{ml})$ and $5 \mathrm{~mm}$ NAMDA $(C)$ after $6 \mathrm{hr}$ of incubation. Note that the marked increase in staining in the presence of LPS $(B)$ was attenuated by NAMDA treatment $(C)$.

in the CA1 region, NADPH-D staining was performed in the hippocampus in rats exposed to $10 \mathrm{~min}$ of ischemia. Compared with sham-operated controls, ischemia increased NADPH-D activity selectively in CA1 but not CA2-CA4 pyramidal layers. The intensity of staining was elevated in the CA1 region at $12 \mathrm{hr}$, peaked at $24 \mathrm{hr}$, and decreased by $3 \mathrm{~d}$ after ischemia (Fig. $6 B-E$ ). The death and disappearance of CA1 pyramidal neurons account for the lack of staining $7 \mathrm{~d}$ after ischemia (Fig. $6 F$ ). Ischemia- 


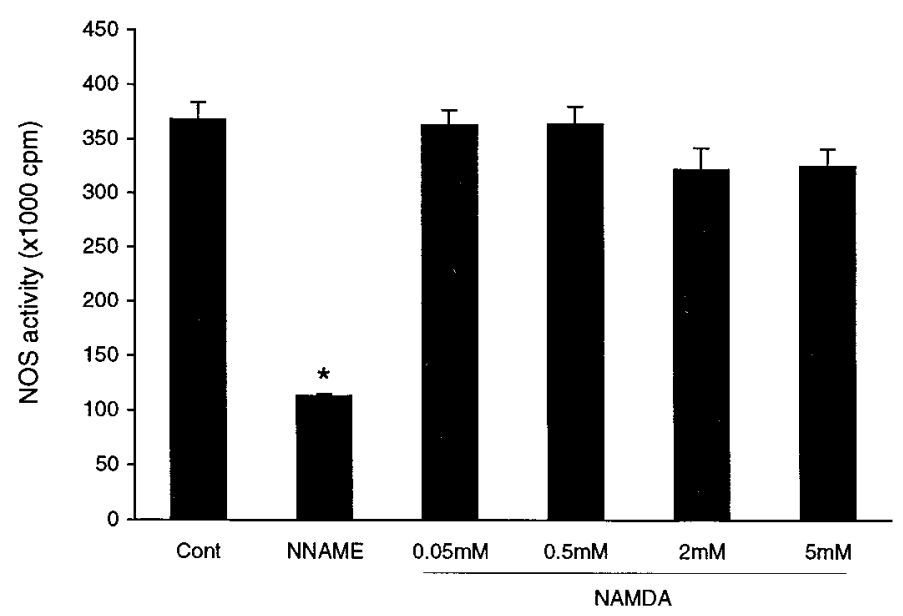

Figure 3. NOS activity in LPS-activated BV-2 cells extracts. The addition of different concentrations of NAMDA to the cell extracts did not change NOS activity. However, the addition of NNAME, a known NOS inhibitor, significantly attenuates NOS activity. ${ }^{*} p<0.001$ versus control (Cont), one-way ANOVA, Newman-Keuls multiple comparison test $(n=4)$.

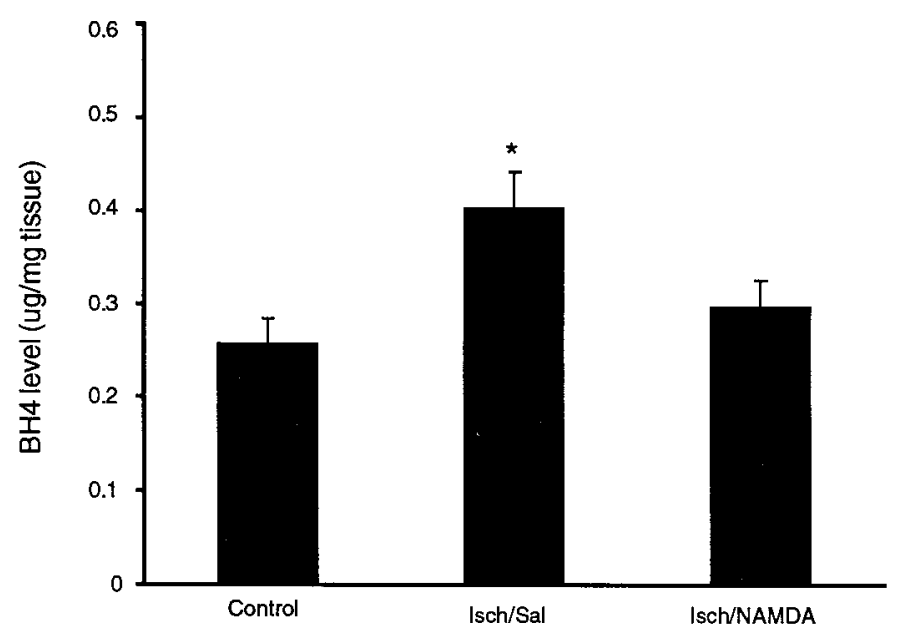

Figure 4. $\mathrm{BH}_{4}$ measurements in the $\mathrm{CA} 1$ hippocampus. $\mathrm{BH}_{4}$ levels were determined in sham-control, saline-ischemic (Isch/Sal), and NAMDAischemic (Isch/NAMDA) rats at $24 \mathrm{hr}$ of reperfusion. Ischemia increased $\mathrm{BH}_{4}$ levels in the CA1 hippocampus at $24 \mathrm{hr}$ of reperfusion. The increase was reversed by NAMDA treatment $(10 \mathrm{mg} / \mathrm{kg}$ at $0,0.5$, and $2 \mathrm{hr}$ of cerebral reperfusion). ${ }^{*} p<0.05$ versus control, one-way ANOVA, Newman-Keuls multiple comparison test ( $n=3-4$ in each group).

induced NADPH-D staining was specifically localized in the cytoplasm of CA1 pyramidal neurons (Fig. 6G, arrows), and these neurons were distinct from intensely stained intrinsic NADPH-D + neurons (Fig. 6G, arrowheads). Ischemia-induced NADPH-D staining was sharply demarcated at the CA1-CA2 junction (Fig. 6H, arrow). Although some degree of NADPH-D staining was present in the regions adjacent to CA2-CA4 pyramidal and dentate granular cell layers, CA2-CA4 pyramidal neurons and granular neurons in dentate gyrus were themselves devoid of staining. The data demonstrate that NADPH-D activity in CA1 pyramidal neurons undergoes a region specific upregulation after ischemia.

To determine the effect of NAMDA on NOS catalytic activity in vivo, NADPH-D staining was examined in the CA1 hippocampus from control and saline- and NAMDA-treated ischemic an- imals. Ischemia-induced NADPH-D activity $24 \mathrm{hr}$ after ischemia was significantly reduced by triple intraperitoneal injections of NAMDA $(10 \mathrm{mg} / \mathrm{kg}, 0,0.5$, and $2 \mathrm{hr}$ of cerebral reperfusion; Fig. $7 A, B, E)$. The attenuation of the NADPH-D staining persisted for $48 \mathrm{hr}$ after ischemia (Fig. 7C,D,E).

\section{Up-regulation of Caspase-3 mRNA in the CA1 hippocampus}

To understand NO-mediated cell death, the expression of genes involved in apoptosis was investigated. Expression of caspase-3 mRNA in the hippocampus was not detected in the control (Fig. $8 A, E$ ) but was significantly and selectively upregulated in the CA1 pyramidal layer at $48 \mathrm{hr}$ after ischemia (Fig. 8B,D,F). Caspase-1 mRNA expression was absent in both the control and ischemic hippocampus at 24 and $48 \mathrm{hr}$ after ischemia (data not shown). More importantly, treatment with NAMDA $(10 \mathrm{mg} / \mathrm{kg}$ at $0,0.5$, and $2 \mathrm{hr}$ of reperfusion) prevented the upregulation of caspase-3 mRNA expression at $48 \mathrm{hr}$ after ischemia (Fig. $8 C, D, G)$. The data indicate that inhibition of $\mathrm{BH}_{4}$, with a subsequent effect on NOS, leads to downregulation of gene expression in a crucial member of the caspase family.

\section{Neuroprotection by NAMDA}

Rats exposed to $10 \mathrm{~min}$ of $4-\mathrm{VO}$ ischemia had their body temperatures recorded for $4 \mathrm{hr}$ of cerebral reperfusion. There were no differences in body temperature between the saline-treated ischemic and NAMDA-treated ischemic groups at any time point recorded (Table 2). These data discount the possibility that NAMDA causes hypothermia.

Neuronal density in the target CA1 hippocampus measured 1 week later demonstrated significant increases in each of the NAMDA-treated ischemic groups compared with the salinetreated ischemic group (Fig. 9; $p<0.0001$ ). Although the greatest protection was achieved in the group that received NAMDA immediately after reperfusion ( $45 \%$ of nonischemic control), delaying the administration up to $2 \mathrm{hr}$ after ischemia still resulted in significant protection of CA1 neurons.

\section{DISCUSSION}

The data demonstrate for the first time that downregulation of $\mathrm{BH}_{4}$ protects neurons exposed to ischemia. This novel candidate neuroprotective mechanism depends on the role of $\mathrm{BH}_{4}$ as a crucial cofactor in the synthesis of NO. The putative mechanism begins with the blockade of $\mathrm{BH}_{4}$ biosynthesis by NAMDA and ends with protection of neurons in the CA1 hippocampus that depends on the downregulation of NADPH-D activity and caspase-3 gene expression. Our in vitro findings that NAMDA inhibits GTPCH activity, with subsequent reduction of NADPH-D activity and nitrite production, without directly acting on NOS activity are consistent with the putative in vivo mechanism.

Several in vitro studies have indicated that intracellular $\mathrm{BH}_{4}$ levels regulate NO synthesis (Werner-Felmayer et al., 1990, 1993; Gross et al., 1991; Rosenkranz-Weiss et al., 1994; Kasai et al., 1997). In the current study, we used NAMDA to block the synthesis of $\mathrm{BH}_{4}$. Incubation of BV-2 cells with up to $5 \mathrm{~mm}$ NAMDA, an analog of $N$-acetyldopamine, did not affect cell viability in contrast to the apparent toxicity induced by comparable concentration of $N$-acetyldopamine (data not shown). Although $N$-acetyldopamine is a sepiapterin reductase inhibitor (Smith et al., 1992), our in vitro study demonstrated that NAMDA inhibited $\mathrm{BH}_{4}$ biosynthesis at the level of GTPCH. However, 

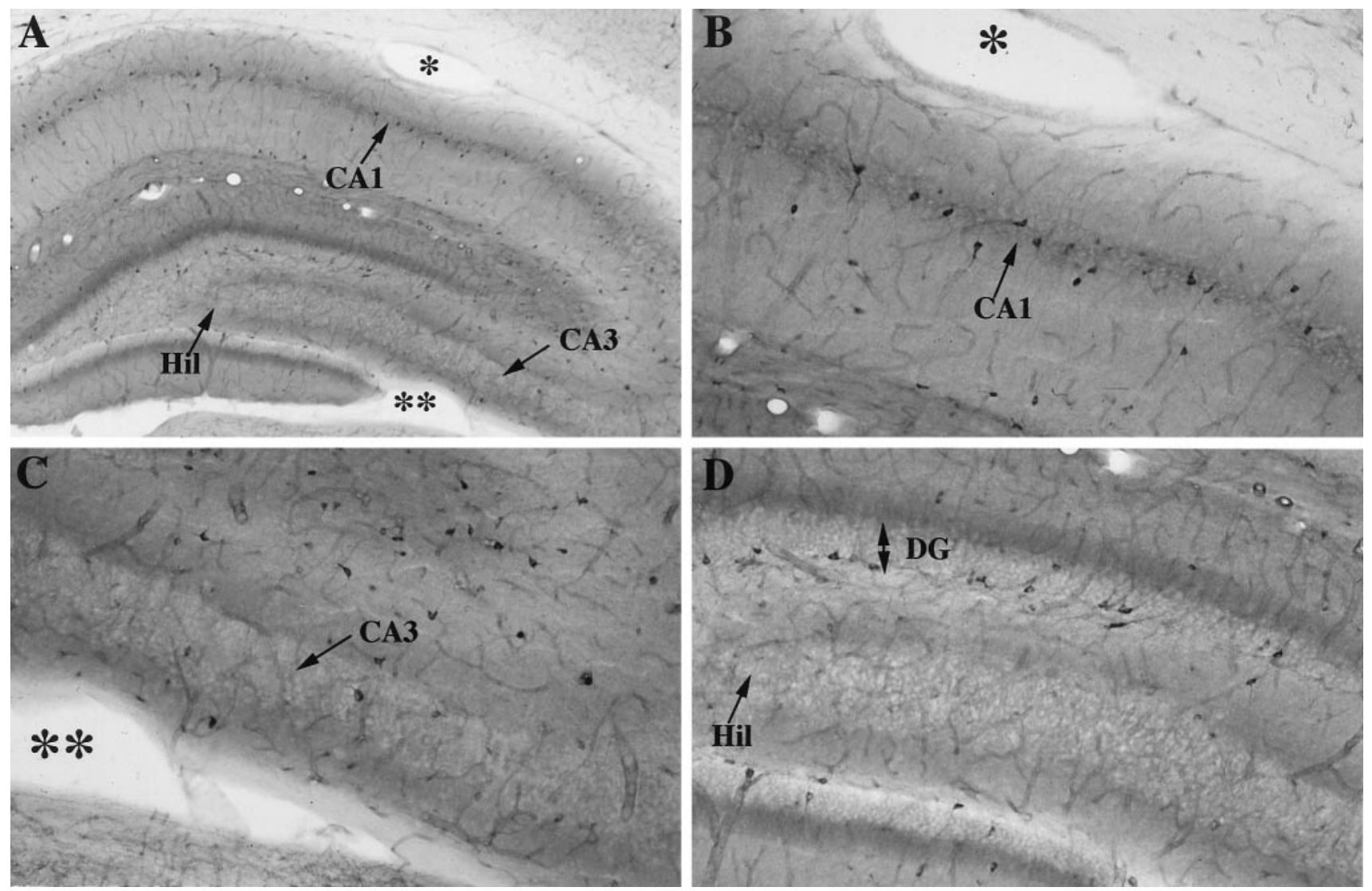

Figure 5. NADPH-D histochemical staining in the control hippocampus. Note the presence of intensely stained NADPH-D+ neurons in CA1 $(A$, low; $B$, high magnification). NADPH-D+ neurons were less numerous in other pyramidal $(C, D)$ and granular $(D)$ cell layers. Hil, Hilus; $D G$, dentate granular cells.

whether NAMDA directly acts on specific activity of GTPCH or on a transcriptional or translational level requires further study.

$\mathrm{BH}_{4}$ is an obligatory cofactor for the activities of all forms of NOS and of monoamine biosynthetic enzymes such as tyrosine hydroxylase (TH) and tryptophan hydroxylase (TPH). Less clear is the mechanism by which $\mathrm{BH}_{4}$ may appear within the locus of target neurons for ischemic injury in the current model and the critical source of NOS and NO formation. We speculate that $\mathrm{BH}_{4}$ may be transported from distant sources to a region of the hippocampus that has, constitutively, large repositories of resistant NOS+/NADPH-D+ neurons in the CA1 region. TH and TPH have been shown, by immunoreactivity and in situ hybridization, to colocalize with GTPCH (Hirayama et al., 1993; Lentz et al., 1993; Hwang et al., 1998) but not with neuronal NOS (nNOS) (Hwang et al., 1998). Instead, double immunostaining of $\mathrm{TH}$ and nNOS in rat striatum revealed that $\mathrm{TH} / \mathrm{GTPCH}+$ fibers terminate near nNOS cell bodies (Hwang et al., 1998). These anatomical data suggest that $\mathrm{BH}_{4}$-containing nerve terminals may donate this cofactor to nNOS-containing cells. That $\mathrm{BH}_{4}$ is taken up into cells (Anastasiadiz et al., 1994) further supports the possibility that the propinquity of $\mathrm{BH}_{4}$-producing $(\mathrm{GTPCH}+)$ terminals and $\mathrm{BH}_{4}$-dependent (NOS+/NADPH-D+) cells might account for cofactor transport.

More specifically, the hippocampus receives monoaminergic afferents from raphe (serotonergic, $\mathrm{GTPCH}+/ \mathrm{TPH}+$ ) and locus ceruleus (noradrenergic, GTPCH $+/ \mathrm{TH}+$ ), and we and others have found NOS+/NADPH-D+ neurons present in the CA1 pyramidal layer of the dorsal hippocampus (O'Dell et al., 1994;
Wendland et al., 1994; Hara et al., 1996) (but see Valschanoff et al., 1993, discussed below). The physical location of these neurons activated by excess $\mathrm{BH}_{4}$ may contribute to selective neuronal injury. In fact, when the hippocampal afferents that included fibers from the raphe and locus ceruleus were severed, there was significant neuroprotection in the CA1 hippocampus after forebrain ischemia (Buchan et al., 1990). Thus, the neuroanatomy is consistent with the notion that monoaminergic fibers that innervate the hippocampus may provide a rich source of $\mathrm{BH}_{4}$, especially after stress such as ischemia. Alternatively, a possibility of a peripheral origin for $\mathrm{BH}_{4}$ induced by postischemic stress cannot be ruled out entirely, because $\mathrm{BH}_{4}$ has been shown to penetrate the blood-brain barrier (Kapatos and Kaufman, 1981).

Some investigators have demonstrated more NADPH-D+/ NOS + neurons in the CA3 than in the CA1 pyramidal layer (Valschanoff et al., 1993). However, we observed numerous intrinsic NADPH-D+ neurons throughout the CA1 pyramidal layer and less NADPH-D+ neurons in the CA2-CA4 pyramidal layers. The discrepancy may depend on the dorsal and ventral location of these neurons. For example, although we and others (O'Dell et al., 1994; Wendland et al., 1994) observed NADPH$\mathrm{D}+/ \mathrm{NOS}+$ neurons in CA1pyramidal layers of anterior dorsal hippocampus, Valschanoff et al. (1993) reported a lack of NADPH-D + neurons in the CA1 pyramidal layers of ventral hippocampus and more numerous NADPH-D+ neurons in the CA3 pyramidal layers of the anterior tip of dorsal hippocampus. Whether relative neuroanatomical position (e.g., anterior-dorsal vs posterior-ventral hippocampus) accounts for the difference in 

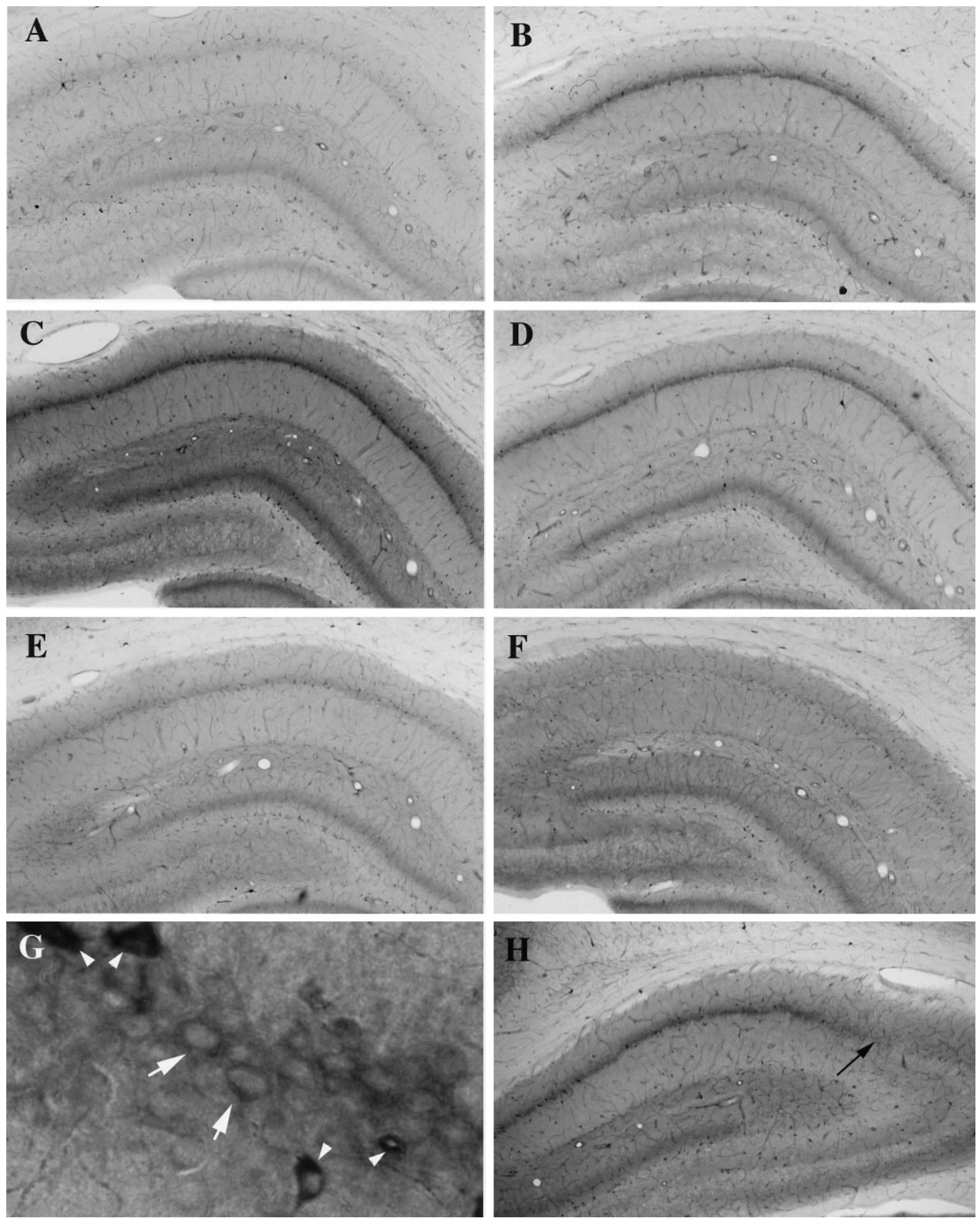

Figure 6. Temporal profile of NADPH-D activity. NADPH-D activity in the postischemic hippocampus in control $(A)$ and $12 \mathrm{hr}(B), 24 \mathrm{hr}(C, G, H)$, $2 \mathrm{~d}(D), 3 \mathrm{~d}(E)$, and $7 \mathrm{~d}(F)$ after 10 min of 4-VO ischemia is shown. Ischemia-induced NADPH-D activity in the CA1 hippocampus was highest 24 $\mathrm{hr}$ after ischemia $(C)$. High magnification of CA1 neurons after $24 \mathrm{hr}$ of ischemia shows cytoplasmic localization of ischemia-induced NADPH-D staining in pyramidal neurons $(G$, arrows). These neurons are distinct from intrinsic NADPH-D+ neurons $(G$, arrowheads). The arrow in $H$ indicates the junction between CA1 and CA2. 

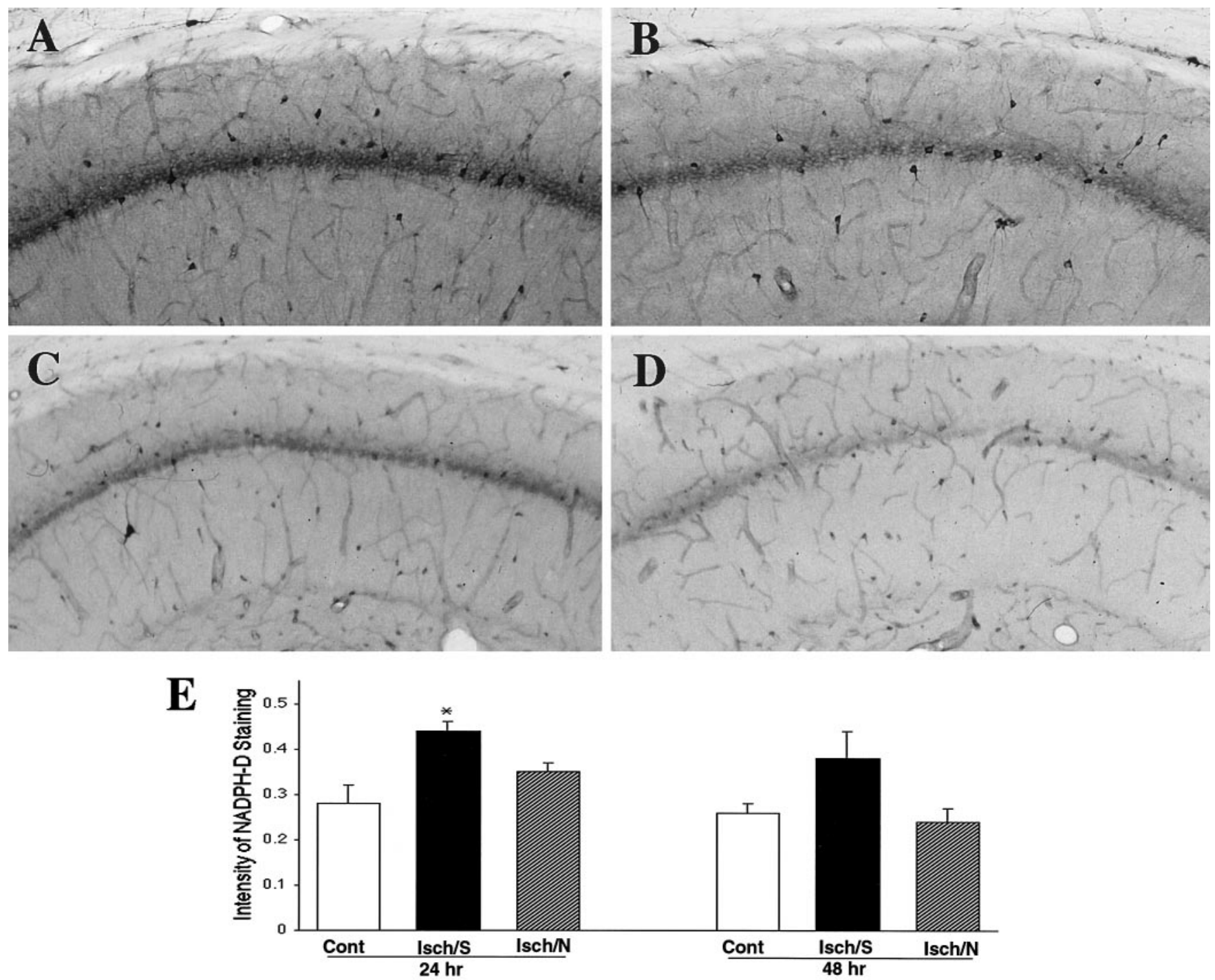

Figure 7. NADPH-D activity in the saline-ischemic $(I s c h / S)$ and NAMDA-ischemic $(I s c h / N)$ CA1 hippocampus. The intensity of ischemia-induced NADPH-D staining was reduced in the CA1 hippocampus of NAMDA-treated $(B, D)$ compared with saline-treated $(A, C)$ animals both at 24 hr $(A, B)$ and $48 \mathrm{hr}(C, D)$ after ischemia. The intensity of NADPH-D staining of sham-operated control (Cont) (Fig. 6A) was comparable to that of an NAMDA-treated $48 \mathrm{hr}$ postischemic animal $(D)$. Quantification of NADPH-D activity shows significant increase in saline-treated ischemic CA1 hippocampus at $24 \mathrm{hr}$ after ischemia $(E) . * p<0.05$ versus control, one-way ANOVA, Newman-Keuls multiple comparison test $(n=3-4$ in each group).

the number of intrinsic NADPH-D+/NOS + neurons deserves further study.

NO production and the regulation of NOS gene expression and protein are profoundly altered in ischemia (Kader et al., 1993; Zhang and Iadecola, 1993; Nagafuji et al., 1994; Zhang et al., 1994; Iadecola et al., 1995b, 1996). Also, mice with targeted disruption of the nNOS gene and exposed to global ischemia demonstrated a reduction in CA1 damage (Panahian et al., 1996). A similar reduction in brain damage occurred in iNOS and nNOS mutant mice after focal ischemia (Huang et al., 1994; Iadecola et al., 1997). Because NADPH-D staining does not distinguish among different isoforms of NOS, there can be no firm conclusion about which NOS is responsible for delayed neuronal injury or about which NOS is blocked by the NAMDA treatment. Clues for the identification of the specific NOS isoform can be taken from the temporal development of injury and the known appearance of NADPH-D activity after ischemia. For example, the expression of nNOS occurs shortly after the induction of isch- emia, whereas iNOS expression is delayed in focal ischemia (Iadecola, 1997). In the current study, ischemia-induced NADPH-D activity in the postischemic CA1 hippocampus occurred early and returned to baseline before the cells died (Fig. 5), consistent with the finding in an ischemic gerbil model (Kato et al., 1994). Ischemia-induced NADPH-D staining was localized in the cytoplasm of CA1 pyramidal neurons at $24 \mathrm{hr}$ after ischemia (Fig. 4G), and astrocytes did not show NADPH-D reactivity at this time. Also, other work demonstrated iNOS expression localized in astrocytes after ischemia (Endoh et al., 1994). Thus, we speculate that early involvement of nNOS, at least partially, is responsible for neuronal injury.

Several in vitro studies have shown that NMDA-mediated NO toxicity or glutamate-induced neuronal death results in both apoptosis and necrosis, depending on the magnitude of the insult (Ankarcrona et al., 1995; Bonfoco et al., 1995). Similarly, both types of cell death may occur after ischemia in vivo, with early necrosis followed by delayed apoptosis. Although recent studies 

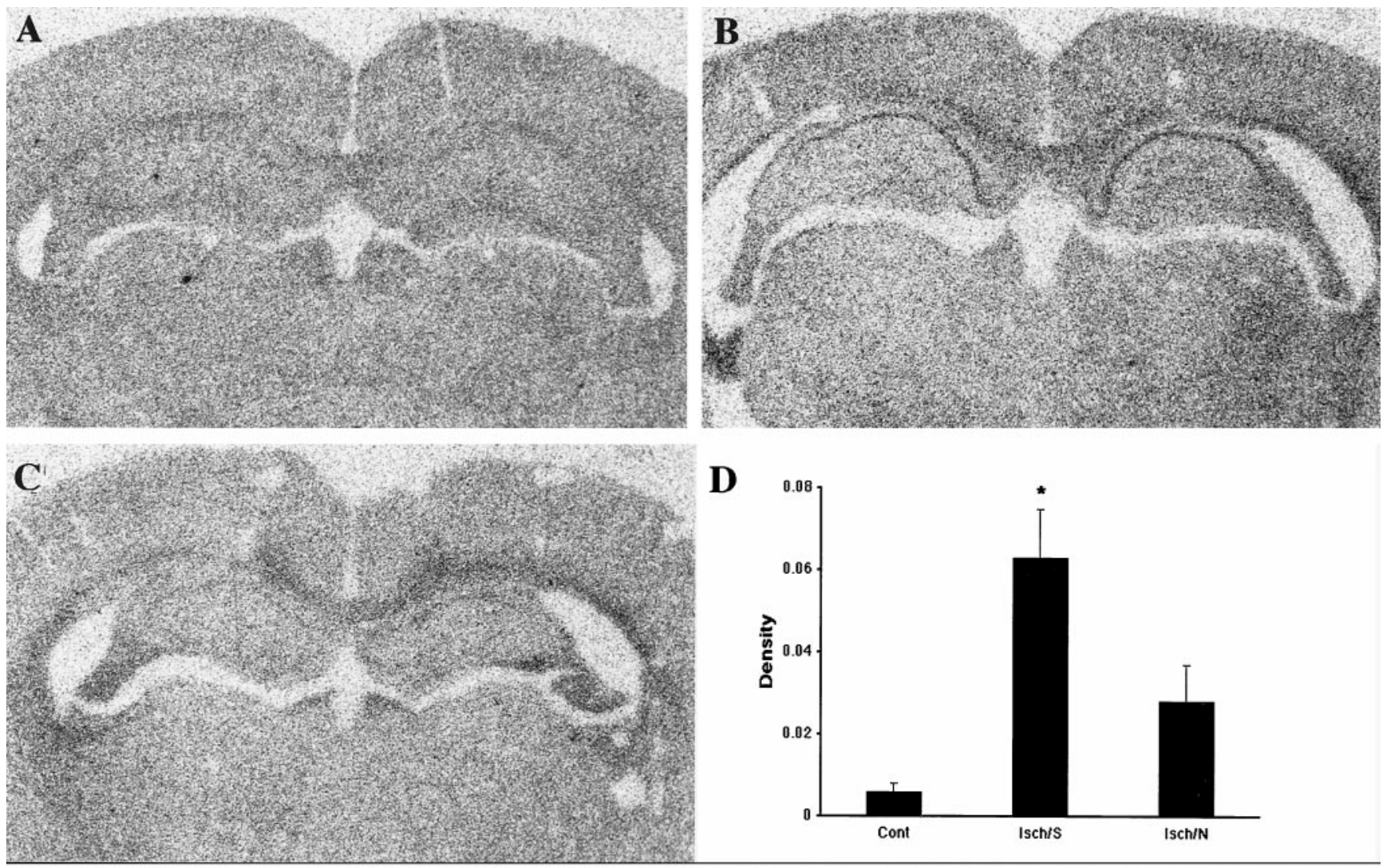

\section{D}
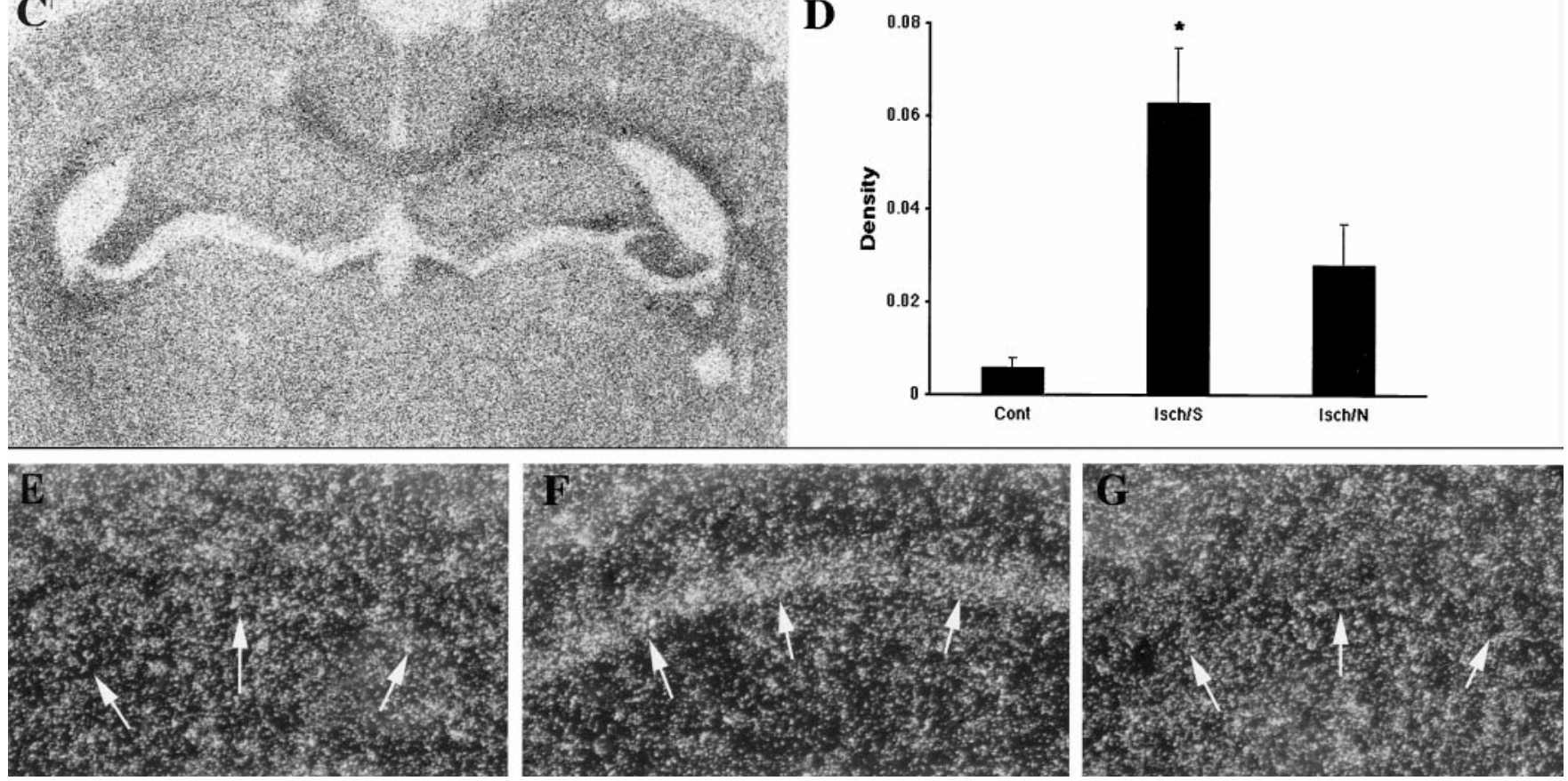

Figure 8. Caspase-3 in situ hybridization. Shown are representative autoradiograms $(A-C)$ and emulsion-coated tissue sections $(E-G)$ at the level of dorsal hippocampus in sham control $(A, E)$, saline-treated ischemic $(B, F)$, and NAMDA-treated ischemic $(C, G)$ rats $48 \mathrm{hr}$ after ischemia. Note that caspase-3 gene expression is confined to the CA1 region of hippocampus $(B, F)$. Compared with control, quantification of caspase-3 mRNA in CA1 hippocampus showed a significant increase in caspase-3 mRNA in saline-treated ischemic $(I s c h / S)$ rats 48 hr after ischemia, and NAMDA (Isch/N) blocked the increase $(D)$. Arrows indicate the CA1 pyramidal layer $(E, F) .{ }^{*} p<0.05$ versus control, one-way ANOVA, Newman-Keuls multiple comparison test ( $n=3-4$ in each group).

suggest that apoptosis after ischemia may be a variant form (Petito et al., 1997), this delayed neuronal death has many of the hallmarks of apoptosis (Nitatori et al., 1995; Volpe et al., 1995). Caspases are known to contribute to cell death in ischemic and excitotoxic brain injury, because inhibition of a family of cysteine proteases reduces ischemic neuronal damage (Hara et al., 1997). Increased expression in caspase-2 (Nedd 2) and caspase-3 (Cpp32, apopain) genes and caspase-like enzyme activity have been reported after ischemia (Asahi et al., 1997; Gillardon et al., 1997; Namura et al., 1998). In animals exposed to transient global ischemia, a role of caspase- 2 and caspase- 3 in proteolysis during neuronal death has also been suggested (Kinoshita et al., 1997; Chen et al., 1998; Ni et al., 1998).

In the current study, the timing of caspase gene expression supports the specific participation of caspase- 3 in neuronal degeneration, but this timing does not specify the locus of NAMDA action. The upregulation of expression of caspase-3, but not caspase-1 (ICE), in the CA1 hippocampus $48 \mathrm{hr}$ after ischemia preceded neuronal death, which typically occurs 5-6 d after ischemia. The early induction of caspase-3 may indicate a role for this protease in neuronal death. Our data are consistent with other recent work on the role of caspase in delayed neuronal death (Chen et al., 1998; Namura et al., 1998). Less clear are the initiating factors for the induction of caspase gene expression. Our data suggest that excess $\mathrm{BH}_{4}$ and $\mathrm{NO}$ may serve as signals, and we hypothesize that inhibition of caspase-3 gene expression after ischemia by NAMDA in CA1 neurons could be a consequence of reduced NO synthesis via sequential reduction of GTPCH activity, $\mathrm{BH}_{4}$ levels, and NOS activity.

The underlying mechanism by which NO contributes to caspase expression and ischemic neuronal death is not clear. However, exposure of NO donors to hypothalamic-derived GT1-7 cells and 


\begin{tabular}{lllll}
\hline \multicolumn{2}{l}{ Table 2. Temperature recordings } \\
Postischemic & $\begin{array}{l}\text { Saline } \\
(n=12)\end{array}$ & $\begin{array}{l}\text { NAMDA } \\
(n=9)\end{array}$ & $\begin{array}{l}\text { NAMDA } \\
(1 \mathrm{hr}) \\
(n=7)\end{array}$ & $\begin{array}{l}\begin{array}{l}\text { NAMDA } \\
(2 \mathrm{hr})\end{array} \\
(n=6)\end{array}$ \\
\hline 0.5 & $37.9 \pm 0.2$ & $37.7 \pm 0.2$ & $37.9 \pm 0.2$ & $38.3 \pm 0.2$ \\
1 & $37.2 \pm 0.1$ & $37.6 \pm 0.2$ & $36.9 \pm 0.1$ & $36.8 \pm 0.3$ \\
1.5 & $37.4 \pm 0.1$ & $37.3 \pm 0.1$ & $37.0 \pm 0.1$ & $37.2 \pm 0.4$ \\
2 & $37.5 \pm 0.2$ & $37.3 \pm 0.1$ & $37.4 \pm 0.1$ & $37.4 \pm 0.2$ \\
3 & $37.6 \pm 0.2$ & $37.5 \pm 0.2$ & $37.5 \pm 0.2$ & $37.3 \pm 0.2$ \\
4 & $37.8 \pm 0.2$ & $37.2 \pm 0.1$ & $37.5 \pm 0.3$ & $37.9 \pm 0.3$
\end{tabular}

$\overline{\text { Body temperature was recorded in saline-ischemic and NAMDA-ischemic animals }}$ during cerebral reperfusion. Triple intraperitoneal injections of saline or NAMDA (10 mg/kg) were given: saline, 0, 0.5, and $2 \mathrm{hr}$; NAMDA, 0, 0.5, and $2 \mathrm{hr}$; NAMDA ( $1 \mathrm{hr}), 1,1.5$, and $3 \mathrm{hr}$; NAMDA (2 hr), 2, 2.5, and $4 \mathrm{hr}$ of cerebral reperf usion. Data are expressed as a mean \pm SEM. ANOVA, Newman-Keuls multiple comparison test, $p>0.05$, NS.

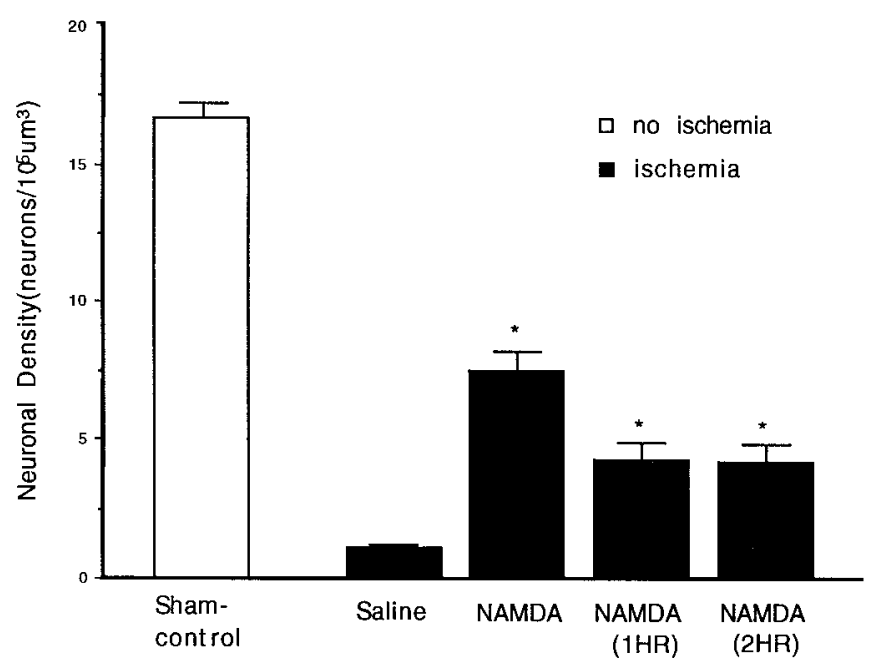

Figure 9. Mean neuronal density in control, saline-ischemic, and NAMDA-ischemic animals. After $10 \mathrm{~min}$ of ischemia, triple intraperitoneal injections of saline or NAMDA $(10 \mathrm{mg} / \mathrm{kg})$ were given [NAMDA, 0 , 0.5 , and $2 \mathrm{hr}$; NAMDA ( $1 \mathrm{hr}), 1,1.5$, and $3 \mathrm{hr}$; NAMDA ( $2 \mathrm{hr}), 2,2.5$, and $4 \mathrm{hr}$ of cerebral reperfusion]. Note that all treatment groups were significantly protected compared with the saline-ischemic group; Sham control, $n=4$; saline, $n=12$; NAMDA, $n=9$; NAMDA ( $1 \mathrm{hr}$ delay), $n=7$; NAMDA ( 2 hr delay), $n=6$; ${ }^{*} p<0.0001$ versus saline, ANOVA, post hoc Fisher's PLSD test.

Raw 264.7 macrophage has resulted in cleavage of poly(ADPribose) polymerase (Bonfoco et al., 1996; Messmer et al., 1996). These in vitro studies support a link between NO-mediated apoptotic signaling and an increase in ICE-like protease activities, the events that ultimately result in cell death.

In summary, $10 \mathrm{~min}$ transient forebrain ischemia increased $\mathrm{BH}_{4}$ levels and upregulated NADPH-D activity in the CA1 hippocampus during cerebral reperfusion. The selective CA1 injury was attenuated by triple administrations of NAMDA, a new GTPCH inhibitor, at $0,0.5$, and $2 \mathrm{hr}$ of reperfusion. Although the degree of protection was less, delaying the treatment by 1 or $2 \mathrm{hr}$ also resulted in significant protection. The occurrence of neuroprotection by NAMDA in vivo coincides with the decrease in $\mathrm{BH}_{4}$ levels, NADPH-D activity, and caspase-3 gene expression in the CA1 hippocampus. The reduction of LPS-induced NO synthesis, NADPH-D, and GTPCH activity by NAMDA in vitro further indicates that the neuroprotective action of NAMDA in rat is mediated in part via reduction of $\mathrm{BH}_{4}$ biosynthesis. Both in vivo and in vitro data support our hypothesis that the increased $\mathrm{BH}_{4}$ level in the CA1 hippocampus during postischemia plays a critical role in NOS activation and selective neuronal injury and suggest that blocking the synthesis of cofactors, $\mathrm{BH}_{4}$ in particular, might form a new therapeutic strategy for stroke.

\section{REFERENCES}

Anastasiadis PZ, Kuhn DM, Levine RA (1994) Tetrahydrobiopterin uptake into rat brain synaptosomes, cultured PC12 cells, and rat striatum. Brain Res 665:77-84.

Ankarcrona M, Dypbukt JM, Bonfoco E, Zhivotovsky B, Orrenius S, Lipton SA, Nicotera P (1995) Glutamate-induced neuronal death: a succession of necrosis or apoptosis depending on mitochondrial function. Neuron 15:961-973.

Asahi M, Hoshimaru M, Uemura Y, Tomoo T, Kojima M, Ohtsuka T, Matsura N, Aoki T, Shibahara K, Kikuchi H (1997) Expression of interleukin-1beta converting enzyme gene family and Bcl2 gene family in the rat brain following permanent occlusion of the middle cerebral artery. J Cereb Blood Flow Metab 17:11-18.

Ashwal S, Cole DJ, Osborne TN, Pearce WJ (1993) Low dose of L-NAME reduces infarct volume in the rat MCAO/reperfusion model. J Neurosurg Anesthesiol 5:241-249.

Beckman JS, Beckman TW, Chen J, Marshall PA, Freeman BA (1990) Apparent hydroxyl radical production by peroxynitrite: implications for endothelial injury from nitric oxide and superoxide. Proc Natl Acad Sci USA 87:1620-1624.

Blasi E, Barluzzi R, Bocchini R, Mazzolla R, Bistoni F (1990) Immortalization of murine microglial cells by a v-raf/v-myc carrying retrovirus. J Neuroimmunol 27:229-237.

Bocchini V, Mazzolla R, Barluzzi R, Blasi E, Sick P, Kettenmann H (1992) An immortalized cell line expresses properties of activated microglial cells. J Neurosci Res 31:616-621.

Bonfoco E, Krainc D, Ankarcrona M, Nicotera P, Lipton SA (1995) Apoptosis and necrosis: two distinct events induced, respectively, by mild and intense insults with $N$-methyl-D-aspartate or nitric oxide/ superoxide in cortical cell cultures. Proc Natl Acad Sci USA 92:7162-7166.

Bonfoco E, Zhivotovsky B, Rossi AD, Aguilar-Santelises M, Orrenius S, Lipton SA, Nicotera P (1996) Bcl2 delay apoptosis and PARP cleavage induced by NO donors in GT1-7 cells. NeuroReport 8:273-276.

Buisson A, Plotkine M, Boulu RG (1992) The neuroprotective effect of a nitric oxide inhibitor in a rat model of focal cerebral ischemia. $\mathrm{Br} \mathrm{J}$ Pharmacol 106:766-767.

Buchan AM, Pulsinelli WA (1990) Septo-hippocampal deafferentation protects CA1 neurons against ischemic injury. Brain Res 512:7-14.

Chen J, Nagayama T, Jin K, Stetler RA, Zhu RL, Graham SH, Simon R (1998) Induction of caspase-3-like protease may mediate delayed neuronal death in the hippocampus after transient cerebral ischemia. J Neurosci 18:4914-4928.

Cho S, Joh TH, Baik HH, Dibinis C, Volpe BT (1997) Melatonin administration protects CA1 hippocampal neurons after transient forebrain ischemia in rats. Brain Res 755:335-338.

Cubells JF, Kim KS, Baker H, Volpe BT, Chung Y, Houpt TA, Joh TJ (1995) Differential in vivo regulation of mRNA encoding norepinephrine transporter and tyrosine hydroxylase in rat adrenal medulla and locus ceruleus. J Neurochem 65:502-509.

Dawson DA, Kusumoto K, Graham DI, McCulloch J, Macrae IM (1992) Inhibition of nitric oxide synthesis does not reduce infarct volume in a rat model of focal cerebral ischaemia. Neurosci Lett 142:151-154.

Dawson TM, Bredt DS, Fotuhi DM, Hwang PM, Synder SH (1991a) Nitric oxide synthase and neuronal NADPH-diaphorase are identical in brain and peripheral tissues. Proc Natl Acad Sci USA 88:7797-7801.

Dawson VL, Dawson TM, London ED, Bredt DS, Snyder SH (1991b) Nitric oxide mediated neurotoxicity in primary cortical cultures. Proc Natl Acad Sci USA 88:6368-6371.

Endoh M, Maiese K, Wagner J (1994) Expression of the inducible form of nitric oxide synthase by reactive astrocytes after transient global ischemia. Brain Res 651:92-100.

Fukushima T, Nixon JC (1980) Analysis of reduced forms of biopterin in biological tissues and fluids. Anal Biochem 102:176-188.

Gillardon F, Bottiger B, Zimmermann M, Hossmann KA (1997) Activation of CPP-32 protease in hippocampal neurons following ischemia and epilepsy. Brain Res Mol Brain Res 50:16-22. 
Green LC, Wagner DA, Glowgowski J, Skipper PL, Wishnok JS, Tannenbaum SR (1982) Analysis of nitrate, nitrite and ${ }^{15} \mathrm{~N}$ nitrate in biological fluids. Anal Biochem 126:131-138.

Gross SS, Jaffe EA, Levi R, Kilbourn RG (1991) Cytokine-activated endothelial cells express an isotype of nitric oxide synthase which is tetrahydrobiopterin-dependent, calmodulin-independent and inhibited by arginine analogs with a rank-order of potency characteristic of activated macrophages. Biochem Biophys Res Commun 178:823-829.

Hamada Y, Hayakawa T, Hattori H, Mikawa H (1994) Inhibitor of nitric oxide synthesis reduces hypoxic-ischemic brain damage in the neonatal rat. Pediatr Res 35:10-14.

Hara H, Waeber C, Huang PL, Fujii M, Fishman MC, Moskowitz MA (1996) Brain distribution of nitric oxide synthase in neuronal or endothelial nitric oxide synthase mutant mice using [3H]L-NG-nitroarginine autoradiography. Neuroscience 75:881-890.

Hara H, Friedlander RM, Gagliardini V, Ayata C, Fink K, Huang Z, Shimizu-Sasamata M, Yuan J, Moskowitz MA (1997) Inhibition of interleukin $1-\beta$-converting enzyme family proteases reduces ischemic and excitotoxic neuronal damage. Proc Natl Acad Sci USA 94:2007-2012.

Hirayama K, Lentz SI, Kapatos G (1993) Tetrahydrobiopterin cofactor biosynthesis: GTP cyclohydrolase I mRNA expression in rat brain and superior cervical ganglia. J Neurochem 61:1006-1014.

Hope BT, Michael CJ, Knigge KM, Vincent SR (1991) Neuronal NADPH diaphorase is a nitric oxide synthase. Proc Natl Acad Sci USA 88:2811-2814.

Huang Z, Huang PL, Panahian N, Dalkara T, Fishman MC, Moskowitz MA (1994) Effects of cerebral ischemia in mice deficient in neuronal nitric oxide synthase. Science 265:1883-1885.

Hwang O, Baker H, Gross S, Joh TH (1998) Localization of GTP cyclohydrolase in monoaminergic but not nitric oxide producing cells. Synapse 28:140-153.

Iadecola C (1997) Bright and dark sides of nitric oxide in ischemic brain injury. Trends Neurosci 20:132-139.

Iadecola C, Xu X, Zhang F, El-Fakahany EE, Ross ME (1995a) Marked induction of calcium-independent nitric oxide synthase activity after focal cerebral ischemia. J Cereb Blood Flow Metab 15:52-59.

Iadecola C, Zhang F, Xu S, Casey R, Ross ME (1995b) Inducible nitric oxide synthase gene expression in brain following cerebral ischemia. J Cereb Blood Flow Metab 15:378-384.

Iadecola C, Zhang F, Casey R, Clark HB, Ross ME (1996) Inducible nitric oxide synthase gene expression in vascular cells after transient focal cerebral ischemia. Stroke 27:1373-1380.

Iadecola C, Zhang F, Casey R, Nagayama M, Ross ME (1997) Delayed reduction of ischemic brain injury and neurological deficits in mice lacking the inducible nitric oxide synthase gene. J Neurosci 17:9157-9164.

Izumi Y, Benz AM, Clifford DB, Zorumski CF (1996) Nitric oxide inhibitors attenuate ischemic degeneration in the CA1 region of rat hippocampal slices. Neurosci Lett 210:157-160.

Kader A, Frazzini VI, Solomon RA, Trifiletti RR (1993) Nitric oxide production during focal cerebral ischemia in rats. Stroke 24:1709-1716.

Kasai K, Hattori Y, Banba N, Hattori S, Motohashi S, Shimoda S, Nakanishi N, Gross SS (1997) Induction of tetrahydrobiopterin synthesis in rat cardiac myocytes:impact on cytokine-induced $\mathrm{NO}$ generation. Am J Physiol 273:H665-H672.

Kapatos G, Kaufman S (1981) Peripherally administered reduced pterins do enter the brain. Science 212:955-956.

Kato H, Kogura K, Liu Y, Araki T, Itoyama Y (1994) Induction of NADPH-diaphorase activity in the hippocampus in a rat model of cerebral ischemia and ischemic tolerance. Brain Res 652:71-75.

Kinoshita M, Tomimoto H, Kinoshita A, Kumar S, Noda M (1997) Up-regulation of Nedd2 gene encoding an ICE/Ced3-like cysteine proteases in the gerbil brain after transient global ischemia. J Cereb Blood Flow Metab 17:507-514.

Kohno K, Ohta S, Furuta S, Kohno K, Kumon Y, Sakaki S (1995) Intraventricular administration of nitric oxide synthase inhibitors prevents delayed neuronal death in gerbil hippocampal CA1 neurons. Neurosci Lett 199:65-68.

Kohno K, Ohta S, Kohno K, Kumon Y, Mitani A, Sakaki S, Kataoka K (1996) Nitric oxide synthase inhibitor reduces delayed neuronal death in gerbil hippocampal CA1 neurons after transient global ischemia without reduction of brain temperature or extracellular glutamate concentration. Brain Res 738:275-280.

Kwon NS, Nathan CF, Stuehr DJ (1989) Reduced biopterin as a cofactor in the generation of nitric oxides by murine macrophages. J Biol Chem 264:20496-20501.

Lentz SI, Hirayama K, Kapatos G (1993) Localization of GTP cyclohydrolase $(\mathrm{GTPCH})$ mRNA in the rat brain by in situ hybridization. Adv Exp Med Biol 338:171-174.

Messmer UK, Reimer DM, Reed JC, Brune B (1996) Nitric oxide induced poly (ADP-ribose) polymerase cleavage in RAW 264.7 macrophage apoptosis is blocked by Bcl2. FEBS Lett 384:162-166.

Nagafuji T, Matsui T, Koide T, Asano T (1992) Blockade of nitric oxide formation by $N$-omega-nitro-L-arginine mitigates ischemic brain edema and subsequent cerebral infarction in rats. Neurosci Lett 147:159-162.

Nagafuji T, Sugiyama M, Matsui T (1994) Temporal profiles of Ca2+/ calmodulin-dependent and -independent nitric oxide synthase activity in the rat brain microvessels following cerebral ischemia. Acta Neurochirug [Suppl] 60:285-288.

Namura S, Zhu J, Fink K, Endres M, Srinivasan A, Tomaselli KJ, Yuan J, Moskowitz MA (1998) Activation and cleavage of caspase-3 in apoptosis induced by experimental cerebral ischemia. J Neurosci 18:3659-3668.

Ni B, Wu X, Su Y, Stephenson D, Smalstig EB, Clemens J, Paul SM (1998) Transient global forebrain ischemia induces a prolonged expression of the caspase- 3 mRNA in rat hippocampal CA1 pyramidal neurons. J Cereb Blood Flow Metab 18:248-256.

Nitatori T, Sato N, Waguri S, Karasawa Y, Araki H, Shibanai K, Kominami E, Uchiyama Y (1995) Delayed neuronal death in the CA1 pyramidal cell layer on the gerbil hippocampus following transient ischemia is apoptosis. J Neurosci 15:1001-1011.

Oddis CV, Finkel MS (1996) NF- $\kappa$ B and GTP cyclohydrolase regulate cytokines-induced nitric oxide production by cardiac myocytes. Am J Physiol 270:H1864-H1868.

O'Dell TJ, Huang PL, Dawson TM, Dinerman JL, Snyder SH, Kandel ER, Fishman MC (1994) Endothelial NOS and the blockade of LTP by NOS inhibitors in mice lacking neuronal NOS. Science 265:542-546.

Pahlmark K, Folbergrova J, Smith ML, Siesjo B (1993) Effects of dimethylthiourea on selective neuronal vulnerability in forebrain ischemia in rats. Stroke 24:731-737.

Patt A, Harken AH, Burton LK, Rodell TC, Piermattei D, Schorr WJ, Parker NB, Berger EM, Horesh IR, Terada LS, Linas SL, Cheronis JC, Repine JE (1988) Xanthin oxidase derived hydrogen peroxide contributes to ischemia reperfusion induced edema in gerbil brains. J Clin Invest 81:1556-1562.

Panahian N, Yoshida T, Huang PL, Hedley-Whyte ET, Dalkara T, Fishman MC, Moskowitz MA (1996) Attenuated hippocampal damage after global cerebral ischemia in mice mutant in neuronal nitric oxide synthase. Neuroscience 72:343-354.

Petito CK, Torres-Munoz J, Roberts B, Olarte JP, Nowak Jr TS, Pulsinelli WA (1997) DNA fragmentation follows delayed neuronal death in CA1 neurons exposed to transient global ischemia in the rat. J Cereb Blood Flow Metab 17:967-976.

Pulsinelli WA, Levy DE, Duffy TE (1982) Regional cerebral blood flow and glucose metabolism following transient forebrain ischemia. Ann Neurol 11:499-502.

Rosenkranz-Weiss P, Sessa WC, Milstien S, Kaufman S, Watson CA, Pober JS (1994) Regulation of nitric oxide synthesis by proinflammatory cytokines in human umbilical vein endothelial cells. Elevations in tetrahydrobiopterin levels enhance endothelial nitric oxide synthase specific activity. J Clin Invest 93:2236-2243.

Sawada M, Horikoshi T, Masada M, Akino M, Sugimoto T, Matsuura S, Nagatsu T (1986) A sensitive assay of GTP cyclohydrolase I activity in rat and human tissue using radioimmunoassay of neopterin. Anal Biochem 154:361-366.

Shapiro S, Kader T, Weissman BV (1994) Dose-dependent effect on nitric oxide synthase inhibition following transient forebrain ischemia in gerbils. Brain Res 668:80-84.

Smith GK, Duch DS, Edelstein MP, Bigham EC (1992) New inhibitors of sepiapterin reductase. J Biol Chem 267:5599-5607.

Stone DM, Wessel T, Joh TH, Baker H (1990) Decrease in tyrosine hydroxylase, but not aromatic L-amino acid decarboxylase, messenger RNA in rat olfactory bulb following neonatal, unilateral odor deprivation. Brain Res Mol Brain Res 8:291-300.

Tayeh MA, Marletta MA (1989) Macrophage oxidation of L-arginine to nitric oxide, nitrite and nitrate: tetrahydrobiopterin is required as a cofactor. J Biol Chem 264:19654-19658.

Valtschanoff JG, Weinberg RJ, Kharazia VN, Nakane M, Schmidt 
HHHW (1993) Neurons in rat hippocampus that synthesize nitric oxide. J Comp Neurol 331:111-121.

Vincent SR, Kimura H (1992) Histochemical mapping of nitric oxide synthase in the rat brain. Neuroscience 46:755-784.

Volpe BT, Wessel TC, Mukherjee B, Federoff HJ (1995) Temporal pattern of internucleosomal DNA fragmentation in the striatum and hippocampus after transient forebrain ischemia. Neurosci Lett 186:157-160.

Volpe BT, Wildmann J, Altar CA (1998) BDNF prevents the loss of nigral neurons induced by excitotoxic striatal lesions. Neuroscience 83:741-748.

Wendland B, Schweizer FE, Ryan TA, Nakane M, Murad F, Scheller R, Tsien R (1994) Existence of nitric oxide synthase in rat hippocampal pyramidal cells. Proc Natl Acad Sci USA 91:2151-2155.
Werner-Felmayer G, Werner ER, Fuchs D, Hausen A, Reibnegger G, Wachter H (1990) Tetrahydrobiopterin-dependent formation of nitrite and nitrate in murine fibroblasts. J Exp Med 172:1599-1607.

Werner-Felmayer G, Werner ER, Fuchs D, Hausen A, Reibnegger G, Schmidt K, Weiss G, Wachter H (1993) Pteridine biosynthesis in human endothelial cells: impact on nitric oxide-mediated formation of cyclic GMP. J Biol Chem 268:1842-1846.

Zhang F, Iadecola C (1993) Nitroprusside improves blood flow and reduces brain damage after focal ischemia. NeuroReport 4:559-562.

Zhang ZG, Chopp M, Gautam S, Zaloga C, Zhang L, Schmidt HH, Pollock JS, Forstermann U (1994) Upregulation of neuronal nitric oxide synthase and mRNA, and selective sparing of nitric oxide synthase-containing neurons after focal cerebral ischemia in rat. Brain Res 654:85-95. 